\title{
The conservation status of the tuco-tucos, genus Ctenomys (Rodentia: Ctenomyidae), in southern Brazil
}

\author{
Fernandes, FA. ${ }^{\mathrm{a}, \mathrm{c}}$, Fernández-Stolz, GP., Lopes, CM. ${ }^{\mathrm{a}, \mathrm{b}}$ and Freitas, TRO., ${ }^{\mathrm{a}, \mathrm{b}, \mathrm{c} *}$ \\ ${ }^{a}$ Departamento de Genética, Instituto de Biociências, Universidade Federal do Rio Grande do Sul - UFRGS, \\ CP 15053, CEP 91501-970, Porto Alegre, RS, Brazil \\ 'Programa de Pós-Graduação em Genética e Biologia Molecular, \\ Universidade Federal do Rio Grande do Sul - UFRGS, Brazil \\ 'Programa de Pós-Graduação em Biologia Animal, Universidade Federal do Rio Grande do Sul - UFRGS, Brazil \\ *e-mail: thales.freitas@ufrgs.br \\ Received May 31, 2007 - Accepted October 5 , 2007 - Distributed December 1, 2007
}

(With 2 figures)

\begin{abstract}
The goal of conservation biology should be related to the preservation of species and also to the evolutionary and ecological processes that were responsible to form them and that are still acting. We review the conservation status of the species of tuco-tuco (Ctenomys torquatus, C. lami, C. minutus, and C. flamarioni) from southern Brazil, and relate these data to the geological history of a particular area in that region, the Coastal Plain of the States of Rio Grande do Sul and Santa Catarina. The implications of the data on these species from the Southeastern Brazil are also discussed in relation to the evolution and risk of extinction of these subterranean rodents.
\end{abstract}

Keywords: Ctenomys, subterranean rodents, hybrid zones, threatened species, Coastal Plain of Rio Grande do Sul.

\section{O status da conservação dos tuco-tucos, gênero Ctenomys (Rodentia: Ctenomyidae), no sul do Brasil}

\begin{abstract}
Resumo
O objetivo da biologia da conservação deve estar relacionado com a preservação das espécies e também com os processos evolutivos e ecológicos que foram responsáveis por sua formação e que continuam ocorrendo. Este trabalho revisa o status de conservação das espécies de tuco-tuco (Ctenomys torquatus, C. lami, C. minutus e C. flamarioni) do sul do Brasil, assim como a relação entre estas informações e a história geológica de uma região de especial importância, a planície costeira dos Estados do Rio Grande do Sul e Santa Catarina. São também discutidas as implicações do conhecimento acumulado sobre as espécies de tuco-tuco no sul do Brasil em relação aos aspectos evolutivos e a ameaça de extinção que estas espécies de roedores subterrâneos sofrem.
\end{abstract}

Palavras-chave: Ctenomys, roedores subterrâneos, zonas híbridas, espécies ameaçadas, planície costeira do Rio Grande do Sul.

\section{Introduction}

Research on species extinctions reveals an accelerating decay of contemporary biodiversity. This pressing environmental problem is likely to be worse in coming decades. Impacts of human activities, although global in scope, are not uniformly distributed. The biotas of certain geographical regions and ecosystems are identified as more endangered, with exceptionally high richness and endemism and exceptionally rapid rates of anthropogenic change (Ceballos et al., 2005).

The goal of conservation biology efforts should be to preserve species and also the evolutionary and ecological processes that were responsible to form them and that and are still acting. These processes include variations in the size of populations and their areas of occurrence,

adaptations to the environment and to other community members (prey, predators, pathogens), and variations in geographic structure over time (demographic and genetic patterns). Therefore, populations in different geographic areas may differentiate genetically because of: a) barriers to gene flow (rivers, mountains, inappropriate habitats); b) isolation by distance (due to limitations in the species' natural dispersal capacity); and c) local adaptation (by natural selection) (Eizirik et al., 2004).

In recent years, we have seen a debate on various methods and approaches that could objectively prioritize conservation values below the species level. The most prominent among these are the evolutionarily significant unit (ESU) and the conservation unit below 
the ESU, termed management unit (MU). Despite the points of disagreement, the different concepts of ESU all aim to define segments of species whose divergence can be measured in light of the evolutionary forces acting on them at different temporal scales (see Fraser and Bernatchez, 2001 for a review). The modern criteria applied to defining conservation units are included in the term adaptive evolutionary conservation (AEC), which constitutes a consensus of the available proposed criteria. The ESU definition under AEC is, 'a lineage demonstrating highly restricted gene flow from other such lineages within the higher organization level (or lineages) of species' and its application in conservation decisions is based on integrative approaches (case-by-case basis; Fraser and Bernatchez, 2001). The focus of the MU is on contemporary population structuring and short-term monitoring rather than on historical factors (Fraser and Bernatchez, 2001).

Conservation of small mammals requires knowledge of the genetically and ecologically meaningful spatial scales at which species respond to habitat modifications. Understanding these facts is important because they represent a major assemblage of species occupying the most varied environments, and their disturbance affects entire community dynamics, because they act, for example, as seed dispersers and as prey. Consequently, effects on small mammals may have cascading effects across the environments where they live (Manning and Edge, 2004).

Rodentia has by far most of the members of all orders of mammals (Novak, 1999). Subterranean rodents, particularly South American tuco-tucos (genus Ctenomys), have attracted special interest in the literature on speciation and evolution, by virtue of their patchy distributions, low vagility, territoriality, and extensive karyotype variation (Reig et al., 1990). The first forms of Ctenomys are recorded to the end of the Pliocene, in central Argentina (Reig and Kiblisky, 1969; Vucetich et al., 1999; Verzi, 2002). Their adaptation to the fossorial habitat, with small physical and ecological variations, allowed the genus to explosively radiate and occupy many different environments. Their geographic distribution extends from the extreme south of the Neotropical region to southern Peru, including the entire Patagonian region, with a wide latitudinal variation, from sea level to $4,000 \mathrm{~m}$ in the Andean region (Reig et al., 1990).

The genus has more than 50 described species and shows high chromosomal variation, with diploid numbers ranging from 10 to $70(\mathrm{FN}=16-84)$. Although there is a wide interspecific chromosomal variation, intraspecific variation also occurs in many species (Freitas, 2006). They can be used as a good model for chromosomal speciation analysis and are considered one of the most rapidly speciating mammalian lineages, including most of the species of all subterranean rodents (Reig et al., 1990).

Despite the great chromosomal variability, some studies have indicated a loss of genetic variability in certain populations because of natural stochastic events and also habitat fragmentation caused by human activities. Among the former, a volcano eruption in Chile was the principal factor leading to loss of genetic variability in some Ctenomys species (Gallardo, 1995). Habitat fragmentation was a factor in the case of $C$. pearsoni in Uruguay (Altuna et al., 1999), and local population extinction of Argentinean tuco-tuco species by human activities was described by Bidau et al. (1996).

In Brazil, eight species of tuco-tucos are described. Three of them, Ctenomys rondoni Miranda Ribeiro, 1914, C. bicolor Miranda Ribeiro, 1914, and C. nattereri Wagner, 1848, are still poorly investigated; only a few records of these species have been collected in the State of Mato Grosso (Miranda Ribeiro, 1914). The type species of the genus, Ctenomys brasiliensis Blainville, 1826, has also been described in Brazil, specifically in the State of Minas Gerais. It has never been collected again in that state, and this is still a matter for investigation. All the other four species of tuco-tuco, Ctenomys torquatus Lichtenstein, 1830, C. minutus Nehring, 1887, C. flamarioni Travi, 1981, and C. lami Freitas, 2001, occur in southern Brazil, in the States of Rio Grande do Sul and Santa Catarina. These four species have been investigated in more details (Freitas and Lessa, 1984; Freitas, 1995, 1997; Silva et al., 2000a,b; Freitas, 2001; Gava and Freitas, 2002; Heuser et al., 2002; Gava and Freitas, 2003, 2004; El Jundi and Freitas, 2004; Freitas, 2006; Freitas, 2007; Fernández-Stolz et al., 2007). Figure 1 shows their geographic distribution.

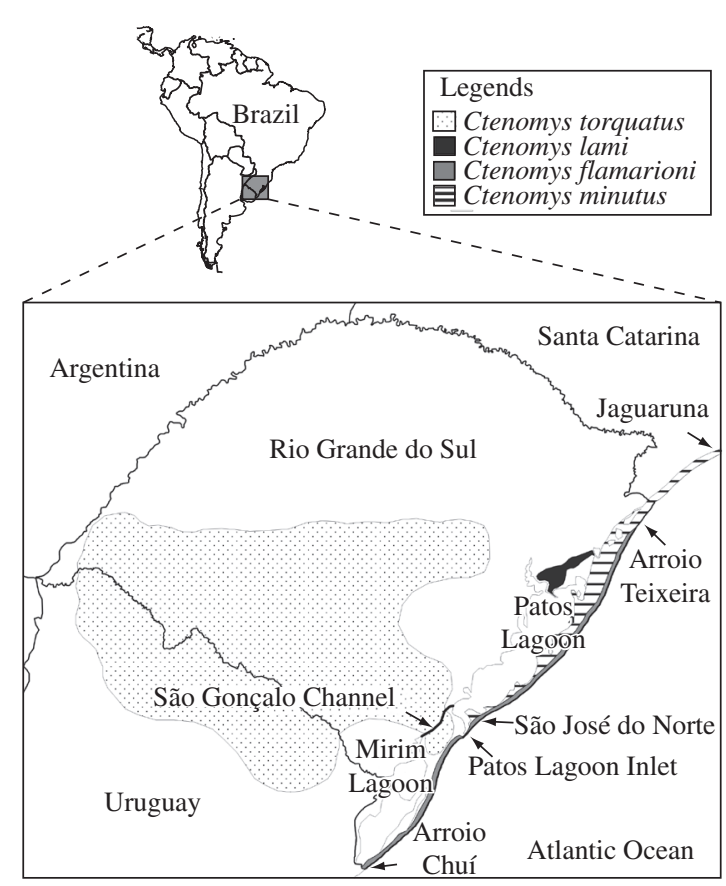

Figure 1. Geographic distribution of Ctenomys in southern Brazil. The most important lakes and rivers are represented. 
We review the conservation status of tuco-tucos in southern Brazil, and relate these data to the geological history of a particular area, the Coastal Plain of Rio Grande do Sul and Santa Catarina. The implications of the data on these species for the evolution and risk of extinction of each of these rodents are also discussed.

\section{Discussion}

\subsection{Ctenomys torquatus}

Reig et al. (1966) considered the "tuco-tuco de colar", Ctenomys torquatus, as living only in Argentina and Uruguay. However, C. torquatus occurs from central Uruguay to southern Brazil, in Rio Grande do Sul State (Freitas, 1995). It occupies lowlands with fields and gallery forests, termed 'Campos Sulinos'. Freitas and Lessa (1984) studied the karyotypes of the Brazilian forms of C. torquatus. They described two diploid numbers for the species: $2 n=44$ and 46 , and proposed that a centromeric fission seems to be the origin of the form with 46 chromosomes. Animals with the latter karyotype have a restricted geographic distribution over a single small area that is isolated from animals with $2 n=44$ by the São Gonçalo Channel and wetlands (Figure 1). This distribution of karyotype forms probably originated at least 2,600 years ago (YA), when the São Gonçalo Channel was formed (Freitas and Lessa, 1984). This chromosomal differentiation, associated with the geographical barriers, makes these tuco-tucos an important model to study processes of genetic differentiation.

In addition to chromosomal polymorphism, chromatic polymorphism is also characteristic of this species. Melanistic individuals were observed in some localities (Cachoeira do Sul and Candiota), and variations in the color of pelage patterns were observed in certain populations, particularly in the city of Alegrete. In this city, populations were characterized by great chromosomal and chromatic variability, with two new karyotypic forms $(2 n=40$ and $2 n=42)$, and at least two other types of pelage pattern (grey and brown with white areas) plus the original brown color pattern (Gonçalves, 2007).

The geographic distribution of $C$. torquatus in Rio Grande do Sul almost coincides with the distribution of coal reserves. They have been utilized as sentinel organisms for coal-mining hazards. Silva et al. (2000a) demonstrated, through comet and micronucleus assays, that coal and its derivatives induced DNA damage and chromosomal lesions in cells of tuco-tucos. Populations from three localities, that correspond to two coal fields - Butiá (in a coal strip-mine region) and Candiota (near a coal strip mine) - and one control region (Pelotas), have been analyzed, and quantitative differences between field exposures have been demonstrated (Pelotas < Butiá $<$ Candiota). Following these studies, C. torquatus was suggested as an excellent organism for use as a biomonitor and bioindicator (Silva et al., 2000b).

\subsection{Ctenomys lami}

Ctenomys lami is an endemic species inhabiting a sandy region named 'Coxilha das Lombas', along a narrow line of old dunes that extends from north of Guaíba Lake to the northwestern sandbanks of Barros Lake (Freitas, 2001; Freitas, 2007). This region is bounded on the northwest by Pachecos Swamp, and on the southeast by Touros Swamp. At present, 'Coxilha das Lombas' contains pastures and human-impacted vegetation.

This species has the highest chromosome variability within Ctenomys, with seven different rearrangements of its diploid numbers: $2 \mathrm{n}=54,55 \mathrm{a}, 55 \mathrm{~b}, 56 \mathrm{a}, 56 \mathrm{~b}, 57$, and 58; and ten different autosomal fundamental numbers (FNa), ranging from 74 to 84 . The diploid number variation was explained by Robertsonian rearrangements occurring in pairs 1 and 2, and the variation of FNa was explained by pericentric inversions (Freitas, 2007). The combined $2 \mathrm{n}$ and $\mathrm{FN}$ form 26 different karyotypes, and their distribution along the $78 \times 12 \mathrm{~km}$ area of collection sites reveals four block populations: block A with $2 \mathrm{n}=$ 54, 55a, and 56a; block B with $2 \mathrm{n}=57$ and 58; block C with $2 \mathrm{n}=54$ and 55 , and block D with $2 \mathrm{n}=56 \mathrm{~b}$ and $55 \mathrm{~b}$ (Figure 2) (Freitas, 1990; Freitas, 2007). Although they share the same diploid number, individuals with karyotypes "a" or "b" were differentiated by their distinct rearrangements and areas of occurrence (Freitas, 2007).

Because chromosomes correspond to the highest levels of differentiation among different markers (Wlasiuk et al., 2003), Freitas (2007) calculated the genetic differentiation by chromosomal rearrangements among the four C. lami population blocks, showing that the high Fst values among them indicate a well-defined population structure in these blocks. This is in agreement with the model proposed by Rieseberg (2001), which states that chromosomal rearrangements affect gene flow.

These genetic and geographical characteristics of C. lami, associated with the progressive urbanization and human occupation of their limited geographic territory, make it a threatened species.

\subsection{Ctenomys minutus}

Ctenomys minutus is morphologically very similar to C. lami, which can lead to misidentification. However, their geographic distributions, karyotypes, and more detailed morphological analyses indicated specific differences (Freitas, 2001). The geographic distribution of Ctenomys minutus begins in Santa Catarina in Laguna Bay, and extends southward to São José do Norte in Rio Grande do Sul (Freitas, 1995; Freygang et al., 2004). Ctenomys minutus has 11 different karyotype forms $(2 \mathrm{n}=50 \mathrm{a}$ and $\mathrm{b} ; 49 \mathrm{a}$ and $\mathrm{b} ; 48 \mathrm{a}$ and $\mathrm{b} ; 47 \mathrm{a}$ and $\mathrm{b} ; 46 \mathrm{a}$ and $b$; and 42) over its range. The chromosome polymorphisms were due to Robertsonian rearrangements and tandem fusions. As observed in specimens of Ctenomys lami, individuals with karyotypes "a" or "b" showed distinct rearrangements and areas of occurrence (Freitas, 1997; Freygang et al., 2004). The distribution of these karyotypes is interesting, because the $2 \mathrm{n}=50$ karyotype 


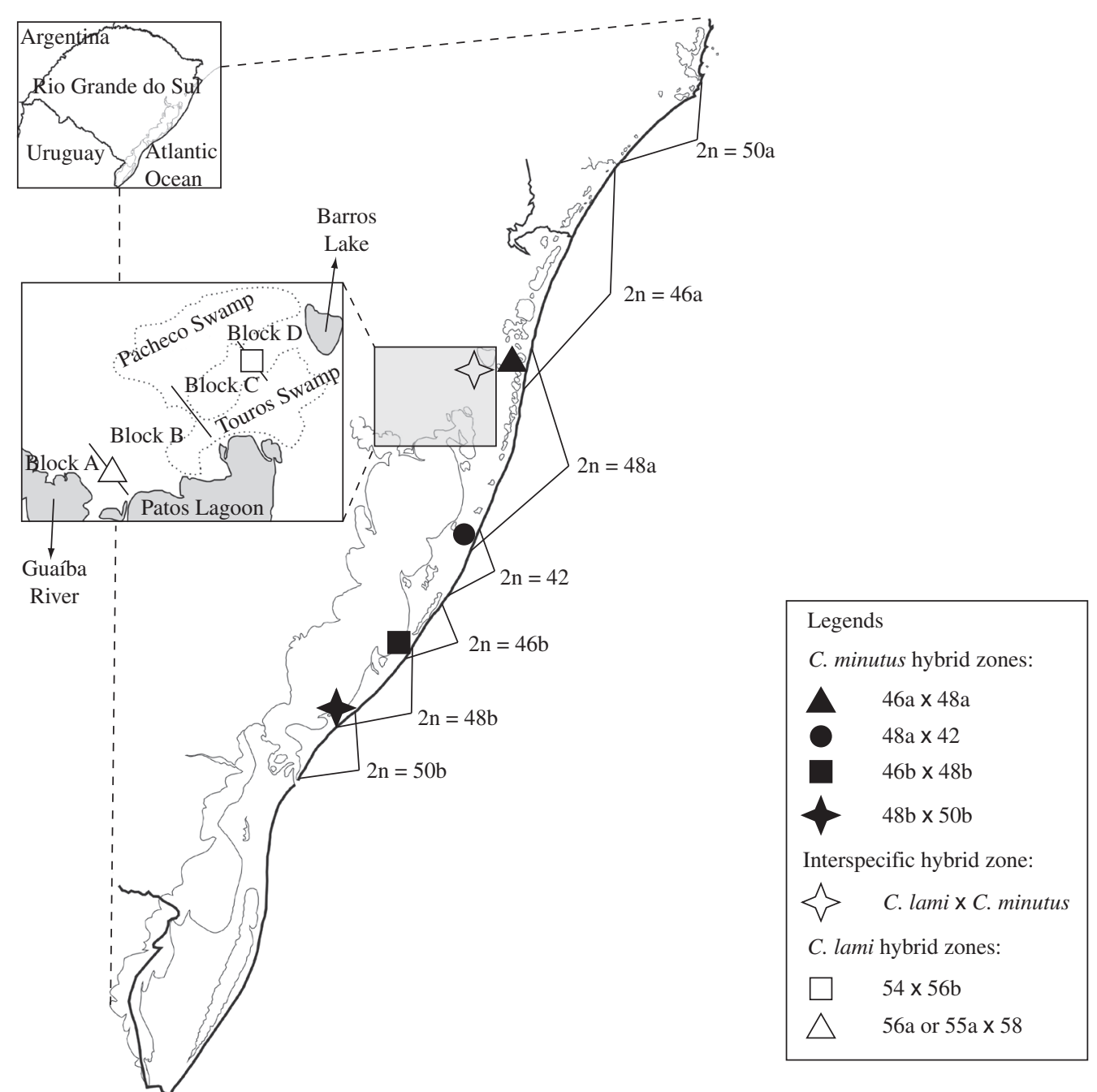

Figure 2. Geographic distribution of Ctenomys in southern Brazil. In detail, the hybrid zones between C. minutus chromosomal populations, $C$. lami chromosomal populations, and between the species C. minutus and C. lami in the Coastal Plain of Rio Grande do Sul.

is found at both ends of its range $(2 \mathrm{n}=50 \mathrm{a}$ and $50 \mathrm{~b})$, but in the center of the chromosomal range it is reduced to $2 n=42$ through chromosomal rearrangements. This suggests that this distribution only occurs because the southern Brazil Coastal Plain is narrow (Freitas, 1997; Freygang et al., 2004). This species was also usable as a genotoxicity biomonitor in regions exposed to vehicle emissions, due to the DNA damage in its cells induced by the environmental pollution (Heuser et al., 2002)

\subsection{Hybrid zones between Ctenomys minutus and C. lami}

Hybrid zones are regions in which genetically distinct populations meet and produce progeny of mixed ancestry. Natural hybridization may occur sporadically between broadly sympatric species, or be confined to a particular geographical contact area (Barton and Hewitt, 1989).
Analyses of gene flow between hybridizing taxa have identified both localized and dispersed introgression of various chromosomal, molecular, biochemical, and morphological characteristics. Studies of the micro- and macro-evolutionary consequences of natural hybridization can suggest the extent to which natural hybridization has been involved in the evolution of extant populations and taxa (Arnold, 1992). The role played by natural hybridization in evolution is generally underappreciated. Strikingly, hybridization can facilitate evolutionary diversification, including the evolution of ecological diversity, as well as the origin of new species, and can also lead to evolutionary innovation, especially via the production of novel genotypes/phenotypes (Ackermann et al., 2006). In another aspect, hybridization can also be responsible for the extinction of species or taxa after contact between them. 
Closely related species or even populations of the same (one) species are often characterized by differences in karyotype. This observation has prompted several authors to argue that chromosomal rearrangements, such as Robertsonian fusions and fissions, translocations, and inversions, may play a causative role in speciation (King, 1993; Rieseberg, 2001). Many theoretical models suggest that chromosomal rearrangements facilitate speciation by accelerating genetic differentiation between populations. Traditional models claimed that rearrangements cause meiotic problems for heterozygous individuals and therefore reduce their fertility and reproductive fitness (King, 1993; White, 1978). In contrast, recent models emphasize a reduction or a suppression of recombination in heterokaryotypes (Rieseberg, 2001). Although each model has unique features, all of them suggest an interesting possibility: gene exchange frequencies should be differentiated according to the chromosome on which these genes are located. Therefore, chromosomal rearrangements should induce barriers or filters to gene flow that would be specific to some parts of the genome (Basset et al., 2006).

Hybrid zones are often cited as "natural laboratories for evolutionary studies" and constitute unique opportunities to understand the early processes involved in the establishment of barriers to gene flow and speciation. These systems are therefore among the most interesting for studying the role of chromosomal rearrangements in speciation (Basset et al., 2006).

The Rio Grande do Sul Coastal Plain is an excellent laboratory for such "natural studies". There is a hybrid zone between $C$. minutus and C. lami (Figure 2) that was formed because of habitat alterations. A wide humid zone, which was a barrier, formerly separated both species. However, around the 1950s, rice culture began to change the swamp into a dry region. This facilitated hybridization of the two species (Gava and Freitas, 2003). Chromosomal rearrangements by Robertsonian fusions should be responsible for new karyotype forms for both species, and their evolutionary future is uncertain. Besides the risk of extinction of local populations of C. minutus and of the species C. lami, the evolutionary processes in which they are involved, such as the hybrid zones near Barros Lake, are also endangered for both species (Freitas, 2001; Gava and Freitas, 2003; Freitas, 2006, 2007).

These hybrid zones showed secondary contact between each karyotype in the Coastal Plain of southern Brazil. Moreover, there is strong evidence of correlation between chromosomal variations and geographic barriers, resulting in a geographical model of speciation followed by chromosomal rearrangements (Freitas, 2006).

Hybrid zones have been also recorded between C. minutus chromosomal populations: one of them occurs at Capivari-Mostardas Road, between populations with $2 \mathrm{n}=42$ and $48 \mathrm{a}$ (Figure 2 ), where one polymorphic population has been sampled (Gava and Freitas, 2003). In another zone, located in the east region of Barros
Lake to the west-southwestern shore of Fortaleza Lake (Figure 2), seven polymorphic populations have been found between $C$. minutus $2 \mathrm{n}=46 \mathrm{a}$ and $48 \mathrm{a}$. Four populations have individuals with $2 \mathrm{n}=46 \mathrm{a}, 47 \mathrm{a}$, and $48 \mathrm{a}$, while the other have only individuals with $2 \mathrm{n}=47 \mathrm{a}$ and 48a (Gava and Freitas, 2002, 2003, 2004). Two other polymorphic sites have been described (Figure 2): one of them between $2 \mathrm{n}=46 \mathrm{~b}$ and $48 \mathrm{~b}$, forming $2 \mathrm{n}=47 \mathrm{~b}$, and the other between the karyotypes $48 \mathrm{~b}$ and $50 \mathrm{~b}$, forming individuals with $2 \mathrm{n}=49 \mathrm{~b}$ (Freygang et al., 2004; Freitas, 2006).

Two very narrow hybrid zones have also been hypothesized between $C$. lami chromosomal populations (Figure 2). The first is characterized by the cytotype $2 n=57$, resulting from breeding of $2 n=56$ a or 55 a with $2 \mathrm{n}=58$. The second zone has individuals with $2 \mathrm{n}=55 \mathrm{a}$, formed by the crossing between $2 n=54$ and $2 n=56 a$ (Freitas, 2007).

\subsection{Ctenomys flamarioni}

Ctenomys flamarioni, called the "tuco-tuco of the dunes", is endemic to the first line of dunes, the most recent depositional system in the Coastal Plain. Its range is bounded by Arroio Teixeira City on the north (Freitas, 1995) and by the Chuí River on the south (Fernández-Stolz et al., 2007).

The tuco-tuco of the dunes has only one karyotype number $(2 \mathrm{n}=48)$, but showed heterochomatic variation with the fundamental number varying from 50 to 78 , along a South-North gradient (Freitas, 1994; Massarini and Freitas, 2005; Freitas, 2006). Its white pelage provides cryptic coloration with the environment. Its body is longer and heavier, and the skull is more robust than the other tuco-tuco species in Rio Grande do Sul. Because of the similarities of phenotypic, chromosomal, and ecological characteristics, several authors hypothesized that $C$. flamarioni differentiated from the Argentinean species Ctenomys australis in the Late Pleistocene (Massarini and Freitas, 2005; Fernández-Stolz, 2007).

Fernández-Stolz (2007) suggested a complex pattern to explain the demographic evolution and occupation history of $C$. flamarioni over its present range. Several issues involved in this pattern are the process that originated the species, probably from a small number of founder individuals, later demographic expansion through the vacant coastal dunes, and the subsequent history of reduction (or reductions) in population size caused by the periodic oscillations in climate and habitat availability influenced by glaciations. On the other hand, the environmental instability that characterizes the Coastal Plain nowadays is an important factor contributing to the population dynamics of $C$. flamarioni (Stolz, 2006) and the phylogeographic patterns observed for the species (Fernández-Stolz, 2007).

A last, modern factor that has profoundly influenced the observed loss of genetic variability and the recent reductions in population size is the urban development in coastal environments (Fernández-Stolz et al., 2007). Development is hypothesized to be one of the most 
important factors guiding the evolutionary destiny of the species associated with this natural environment (Fernández-Stolz et al., 2007).

This tuco-tuco species, described only 25 years ago, has been included in the National List of Species of the Brazilian Endangered Fauna, as vulnerable (IBAMA, 2007), and in the List of Endangered Fauna in Rio Grande do Sul (Fontana et al., 2003). The genetics, demographics, and environmental characteristics of C. flamarioni urgently require decisions on appropriate management to counteract the risk of extinction of the species (Fernández-Stolz et al., 2007).

As a first approach to this goal, Fernández-Stolz (2007) defined two Evolutionary Significant Units (ESUs) for C. flamarioni, based on the patterns of variation and divergence from two kinds of markers (mitochondrial and nuclear loci) and previous allozyme (Moreira et al., 1991) and karyotype studies (Freitas, 1994). The first ESU includes the populations from the north of the Patos Lagoon inlet (see Figure 1), and the second, the populations from the southern part of the range, below the Patos Lagoon inlet. Based on the patterns of variation and divergence of nuclear microsatellite loci and the suggested historical connection among populations, Fernández-Stolz (2007) proposed that each of the sampled populations should constitute an independent management unit (MU).

\subsection{The vulnerability of the Coastal Plain species of Ctenomys}

According to Villwock et al. (1989), along the development of the Rio Grande do Sul coast, four geological barriers were created during the Pleistocene and early Holocene by at least four successive transgressionregression marine cycles. Combining the evolution of the Coastal Plain and the geographic distribution of the tuco-tuco species in this region, we observe that $C$. lami lives in the first barrier ('Coxilha das Lombas') formed by the first transgression-regression marine cycle in the Pleistocene (estimated at 400,000 YA); C. minutus and $C$. torquatus populations with $2 \mathrm{n}=46$ live in the second and third barriers (originated about 325,000 YA and 120,000 YA, respectively); and C. flamarioni and C. minutus populations with $2 \mathrm{n}=46 \mathrm{a}$ and $50 \mathrm{a}$ inhabit the last barrier (Freitas, 1995; Fernández-Stolz, 2007; Fernández-Stolz et al., 2007; Freitas, 2007) formed by the transgression-regression marine cycle in the Holocene (Tomazelli et al., 2000).

Several studies have addressed coastal erosion in Rio Grande do Sul, indicating both natural and humaninduced contributing factors over the long and short terms (Esteves et al., 2002; Tomazelli and Villwock, 2000). Anthropogenic changes such as urbanization in active dune areas, shore armoring, sand mining, jetty construction (Tomazelli and Villwock, 2000), the presence of some kinds of domestic animals, and exotic vegetation have modified the natural landscape for years (Fernández-Stolz, 2007). As a result of human activity such as urbanization, native habitats have become in- creasingly fragmented or destroyed. Both habitat loss and isolation of patches resulting from fragmentation can reduce population sizes to levels that lead to genetic drift, inbreeding, and loss of genetic variation and evolutionary potential (Frankham et al., 1999; Lande, 1995).

Other factors that are considered a conservation problem for the Coastal Plain fauna are global warming and rise in sea level. Since the earth's climate has warmed by $0.5{ }^{\circ} \mathrm{C}$ over the past century, the effects of this climate change on ecological systems have been detected in many studies, suggesting that global change may be a current and future conservation threat (McCarty, 2001).

Sea level is the measurement that best synthesizes the influences of various global climate changes, particularly oceanic processes. Sea levels are expected to rise as a result of global warming, with adverse effects on many animal and plant species that live in coastal areas (Church, 2001), and it must represent a dramatic situation for the tuco-tuco species of the Coastal Plain of Rio Grande do Sul. Ctenomys flamarioni is the most endangered species, because it inhabits the first line of dunes only a few meters from the sea; a rise in sea level may drive it to extinction. The same can occur in C. minutus, because this rodent also occur in the first dune line in southern Santa Catarina and northern Rio Grande do Sul, and in $C$. torquatus populations with $2 n=46$ that inhabit the southernmost part of the Rio Grande do Sul Coastal Plain.

\subsection{Conservation and the real risk of extinction of tuco-tucos}

Tuco-tucos are at risk of predation by humans because they have been considered, for decades, due to their fossorial habit, as agricultural pests (Pearson, 1968; Massoia, 1970). In Brazil, lack of knowledge about these small mammals' areas of occurrence and life history has contributed to difficulties in developing preservation initiatives.

Undoubtedly, because of its habitat specificity, the most endangered tuco-tuco species in southern Brazil is Ctenomys flamarioni. The dunes where it lives are contracting because of urban development, and this animal digs holes in house gardens, which turns it rarely welcome. But it is not alone. Another tuco-tuco under threat of extinction is $C$. lami. Although it is not included in the National List of Species of the Brazilian Threatened and Endangered Fauna, this rodent occurs in a very narrow range. Its extinction could lead to a great loss of genetic diversity, since it shows the most chromosomal variability among Ctenomys species (Freitas, 2007). The planned urbanization and the development of agriculture, particularly rice and soybeans, put the geographic distribution and the process of differentiation and evolution of this species at risk.

Despite its wide geographic distribution, C. torquatus is also endangered in Brazil. In the sand fields in central and southern Rio Grande do Sul, agriculture has developed rapidly since the 1960 s, particularly soybean, Pinus and Eucalyptus plantations. Other important factors 
placing its populations at risk are environmental changes such as floods and droughts (Bertê, 2004), and coal mining, a genotoxicity factor for $C$. torquatus populations (Silva et al. 2000b). In addition, the coal reserves that overlap the areas where this tuco-tuco lives probably have disturbed their habitats (Freitas, 1995).

The accumulated genetic results, combined with physiological, ecological, and ethological data, provide a multifaceted perspective of the process of species conservation. An emerging role of population genetics, phylogenetics, and phylogeography as indicators of a population's natural history and its future prognosis, provides valuable data for use in the development of conservation management plans for endangered species (O’Brien, 1994).

Considering the state of the knowledge about tucotucos in Brazil, we can affirm that the vulnerability of these subterranean rodents is greater than presently supposed. More studies should be performed at molecular and ecological levels, and protected areas must be set aside to preserve these species and their extraordinary evolution processes.

Acknowledgments - This report was possible trough essential contributions from Adriana Gava, Camila Castilho, Carla Freitas, Cristina Freygang, Enrique Lessa, Gislene Lopes Gonçalves, José Stolz, Jorge Marinho, Juliana da Silva, Luiz Flamarion B. de Oliveira, Renata Coura, Rodrigo Forne 1, Simone Ximenez, Tarik J.A.R. El Jundi, Tatiane Noviski, Tatiane Trigo, Vanina Heuser, and Vitor Hugo Travi. Janet W. Reid revised the English text. The research was supported by CAPES, CNPq, and FAPERGS.

\section{References}

ACKERMANN, RR., ROGERS, J. and CHEVERUD, JM., 2006. Identifying the morphological signatures of hybridization in primate and human evolution. J. Hum. Evol., vol. 51, no. 6, p. 632-645.

ALTUNA, CA., FRANCESCOLI, G., TASSINO, B. and IZQUIERDO, I., 1999. Ecoetologia y conservación de mamíferos subterráneos de distribución restringida: El caso de Ctenomys pearsoni (Rodentia, Octodontidae) en el Uruguay. Etología, vol. 7, p. 47-54.

ARNOLD, ML., 1992. Natural hybridization as an evolutionary process. Annu. Rev. Ecol. Syst., vol. 23, p. 237-261.

BARTON, NH. and HEWITT, GM., 1989. Adaptation, speciation and hybrid zones. Nature, vol. 341, p. 497-502.

BASSET, P., YANNIC, G., BRÜNNER, H. and HAUSSER, J., 2006. Restricted gene flow at specific parts of the shrew genome in chromosomal hybrid zones. Evolution, vol. 60, no. 8, p. $1718-1730$.

BERTÊ, AMA., 2004. Problemas ambientais no Rio Grande do Sul: uma tentativa de aproximação. In VERDUM, R., BASSO, LA. and SUERTEGARAY, DMA. (eds). Rio Grande do Sul: Paisagens e territórios em transformação. Ed. UFRGS. Porto Alegre p. 71-83.

BIDAU, CJ., GIMENEZ, MD. and CONTRERAS JR., 1996. Especiación cromosómica y la conservacion de la variabilidad genética: El caso del género Ctenomys (Rodentia, Caviomorpha, Ctenomyidae). Mendeliana, vol. 12, no. 1, p. 25-37.
CEBALLOS, G., EHRLICH, PR., SOBERO, J., SALAZAR, I. and FAY, JP., 2005. Global mammal conservation: What must we manage? Science, vol. 309, no. 5734, p. 603-607.

CHURCH, JA. 2001. How fast are sea levels rising? Science, vol. 294, p. 802-803.

EIZIRIK, E., JOHNSON, WE. and O'BRIEN, SJ., 2004. Definindo unidades evolutivamente significativas e unidades de manejo para a conservação de carnívoros neotropicais. In MORATO, RG., RODRIGUES, FHG., EIZIRIK, E., MANGINI, PR., AZEVEDO FCC. and MARINHO-FILHO, JS. (org.). Manejo e conservação de carnívoros neotropicais. São Paulo: IBAMA, p. 47-66.

EL JUNDI, TARJ. and FREITAS, TRO., 2004. Genetic and demographic structure in a population of Ctenomys lami (Rodentia - Ctenomyidae). Hereditas, vol. 140, no. 1, p. 18-23.

ESTEVES, LS., TOLDO, JR., EE., DILLENBURG, SR. and TOMAZELLI, LJ., 2002. Long- and short-term coastal erosion in Southern Brazil. J. Coastal Res., vol. 36, n. 36 (Special Issue) p. 273-282.

FERNÁNDEZ-STOLZ, GP., 2007. Estudos evolutivos, filogeográficos e de conservação em uma espécie endêmica do ecossistema de dunas costeiras do sul do Brasil, Ctenomys flamarioni (Rodentia - Ctenomyidae), através de marcadores moleculares microssatélites e DNA mitocondrial. 179p. (Tese de Doutorado) - Universidade Federal do Rio Grande do Sul, Porto Alegre, RS.

FERNÁNDEZ-STOLZ, GP., STOLZ, JFB. and FREITAS, TRO., 2007. Bottlenecks and dispersal in the tuco-tuco-dasdunas, Ctenomys flamarioni (Rodentia: Ctenomyidae) in southern Brazil. J. Mammal., vol. 88, no. 4, p. 935-945.

FONTANA, CS., BENCKE, GA. and REIS, RE., 2003. Livro Vermelho da Fauna Ameaçada de Extinção no Rio Grande do Sul. Porto Alegre, EDIPUCRS. 632p.

FRANKHAM, R., MONTGORMERY, ME., ENGLAND, PR., LOWE, EH. and BRISCOE, DA., 1999. Do population size bottlenecks reduce evolutionary potential? Anim. Conserv., vol. 2, no. 4, p. 255-260.

FRASER, DJ. and BERNATCHEZ, L., 2001. Adaptive evolutionary conservation: towards a unified concept for defining conservation units. Mol. Ecol., vol. 10, n. 12, p. 2741-2752.

FREITAS, TRO., 1990. Estudos citogenéticos e craniométricos em três espécies do gênero Ctenomys. 235p. (Tese de Doutorado) - Universidade Federal do Rio Grande do Sul, Porto Alegre, RS.

-, 1995. Geographic distribution and conservation of four species of the genus Ctenomys in southern Brazil. Stud. Neotrop. Fauna \& Environ., vol. 30, no. 1, p. 53-59.

-, 1997. Chromosome polymorphism in Ctenomys minutus (Rodentia-Octodontidae). Rev. Brasil. Genet., vol. 20, no. 1, p. 1-7.

-, 2001., Tuco-tucos (Rodentia, Octodontidae) in southern Brazil: Ctenomys lami Spec. Nov. separated from C. minutus Nehring 1887. Stud. Neotrop. Fauna \& Environ., vol. 36, no. 1, p. 1-8.

-, 2006. Cytogenetics status of four Ctenomys species in the South of Brazil. Genetica, vol. 126, no. 1, p. 227-235.

-, 2007. Ctenomys lami: the highest chromosomal variability in Ctenomys (Rodentia, Ctenomyidae) due to a centric fusion/ 
fission and pericentric inversion system. Acta Theriol., vol. 52, no. 2, p. 171-180.

FREITAS, TRO. and LESSA, EP. 1984. Cytogenetics and morphology of Ctenomys torquatus (Rodentia - Octodontidae). J. Mammal., vol. 65, no. 4, p. 637-642.

FREYGANG, CC., MARINHO, JR. and FREITAS, TRO., 2004. New karyotypes and some considerations about the chromosomal diversification of Ctenomys minutus (Rodentia: Ctenomyidae) on the Coastal Plain of the Brazilian state of Rio Grande do Sul. Genetica, vol. 121, no. 2, p. 125-132.

GALLARDO, MH., 1995. Genética y demografia en Ctenomys (Rodentia; Ctenomyidae) en hábitats fragmentados. Marmosiana, vol. 1, p. 34-42.

GAVA, A. and FREITAS, TRO., 2002. Characterization of a hybrid zone between chromosomally divergent populations of Ctenomys minutus (Rodentia; Ctenomyidae). J. Mammal., vol. 83 , no. 3 , p. 843-851.

-, 2003. Inter and intra-specific hybridization in tucotucos (Ctenomys) from Brazilian Coastal Plains (Rodentia: Ctenomyidae). Genetica, vol. 119, no. 1, p. 11-17.

-, 2004. Microsatellite analysis of a hybrid zone between chromosomally divergent populations of Ctenomys minutus from southeastern Brazil (Rodentia: Ctenomyidae). J. Mammal., vol. 85 , no. 6 , p. 1201-1206.

GONÇALVES, GL., 2007. Diferenciação genética e geográfica intra-específica em Ctenomys Blainville, 1826 (Mammalia: Rodentia) nos Campos Sulinos. 83p. (Dissertação de Mestrado) Universidade Federal do Rio Grande do Sul, Porto Alegre, RS.

HEUSER, VD., SILVA, J., DIAS, JF., YONEAMA, ML. and FREITAS, TRO., 2002. Genotoxicity biomonitoring in regions exposed to vehicle emissions using the comet assay and the micronucleus test in native rodent Ctenomys minutus. Environ. Mol. Mutagen., USA, vol. 40, no. 4, p. 227-235.

IBAMA - Instituto Brasileiro do Meio Ambiente e dos Recursos Naturais Renováveis, 2007. www.ibama.gov.br. [Access: May 24, 2007]

KING, M., 1993. Species evolution. Cambridge,UK, University Press. 336p.

LANDE, R., 1995. Breeding plans for small populations based on the dynamics of quantitative genetic variance. In BALlOU, JD., GILPIN, M. and FOOSE, TJ. (eds.) Population Management for Survival and Recovery. New York, Columbia University Press, p. 318-340.

MANNING, JA. and EDGE, WD., 2004. Small mammal survival and downed wood at multiple scales in managed forests. J. Mammal., vol. 85, no. 1, p. 87-96.

MASSARINI, AI. and FREITAS, TRO., 2005. Morphological and cytogenetics comparison in species of the mendocinusgroup (genus Ctenomys) with emphasis in C. australis and $C$. flamarioni (Rodentia-Ctenomyidae). Caryologia, vol. 58, no. 1, p. 21-27.

MASSOIA, E., 1970. Mamíferos que contribuyen a deteriorar suelos y pasturas en la República Argentina. IDIA, INTA, vol. 276, p. 14-17.

MCCARTY, JP., 2001. Ecological consequences of recent climate changes. Conserv. Biol., vol. 15, no. 2, p. 320-331.
MIRANDA RIBEIRO, A., 1914. História Natural. Zoologia. Commissão de Linhas telegraphicas estratégicas de MattoGrosso ao Amazonas.

MOREIRA, DM., FRANCO, MHLP., FREITAS, TRO. and WEIMER, TA. 1991. Biochemical polymorphisms and phenetic relationships in rodents of the genus Ctenomys from southern Brazil. Biochem. Genet., vol. 29, no. 11-12, p. 601-615.

NOVAK, RM., 1999. Walker's mammals of the world. $6^{\text {th }}$ edition. Maryland, USA, The Johns Hopkins University Press. 1629 p.

O'BRIEN, SJ., 1994. A role for molecular genetics in biological conservation. Proc. Nati. Acad. Sci. USA, vol. 91, no. 13, p. $5748-5755$.

PEARSON, O., BINSZTEIN, N., BOIRY, L., BUSCH, C., DI PACE, M., GALLOPIN, G., PENCHASZADEH, P. and PIANTANIDA, MJ., 1968. Estructura social, distribución espacial y composición por edades de una población de tucotucos (Ctenomys talarum). Investigaciónes Zoológicas Chilenas, vol. 13 , p. 47-79.

REIG, OA., CONTRERAS, JR. and PIANTANIDA, MJ., 1966. Contribución a la elucidación de la sistematica de las entidades del genero Ctenomys (Rodentia, Octodontidae). Contribuciones Científicas de la Faculdad de Ciencias Exactas y Naturales de la Universidad de Buenos Aires (Zoología), vol. 2, no. 6, p. 297-352.

REIG, OA. and KIBLISKY, P., 1969. Chromosome multiformity in the genus Ctenomys (Rodentia: Octodontidae). Chromosoma, vol. 28 , no. 2, p. 211-244.

REIG, OA., BUSCH, C., CONTRERAS, MO. and ORTELLS, JR., 1990. An overview of evolution, systematics, population and speciation in Ctenomys. In NEVO, E. and REIG, OA. (eds.) Evolution of subterranean mammals at the organismal and molecular levels. New York, Wiley-Liss, p. 71-96.

RIESEBERG, LH., 2001. Chromosomal rearrangements and speciation. Trends Ecol. Evol., vol. 16, no. 7, p. 351-358.

SILVA, J., FREITAS, TRO., HEUSER, VD., MARINHO, JR., BITTENCOURT, F., CERSKI, CTS., KLASSMANN, LS. and ERDTMANN, B., 2000a. Chronic exposure to coal in wild rodents (Ctenomys torquatus) evaluated with multiple methods and tissues. Mutat. Res., vol. 470, no. 1, p. 39-51.

SILVA, J., FREITAS, TRO., HEUSER, VD., MARINHO, JR. and ERDTMANN, B., 2000b. Genotoxicity biomonitoring in coal regions using wild rodent Ctenomys torquatus by comet assay and micronucleus test. Environ. Mol. Mutagen., vol. 35, no. 4 , p. $270-278$.

STOLZ, JFB., 2006. Dinâmica populacional e relações espaciais do tuco-tuco-das-dunas (Ctenomys flamarioni Rodentia - Ctenomyidae) na estação ecológica do Taim - RS/ Brasil. 66p. (Dissertação de Mestrado) - Universidade Federal do Rio Grande do Sul, Porto Alegre, RS.

TOMAZELLI, LJ. and VILLWOCK, JA., 2000. O Cenozóico no Rio Grande do Sul: Geologia da Planície Costeira. In HOLZ, M. and DE ROS, LF. (eds.) Geologia do Rio Grande do Sul. Porto Alegre, CIGO/UFRGS, p. 375-406.

TOMAZELLI, LJ., DILLENBURG, SR. and VILLWOCK, JA., 2000. Late quaternary geological history of Rio Grande do Sul Coastal Plain, southern Brazil. Rev. Bras. Geocienc., vol. 30, no. 3 , p. $474-476$. 
VERZI, DH. 2002. Patrones de evolución morfológica en Ctenomyinae (Rodentia, Octodontidae). Mastozoología Neotrop., vol. 9, no. 2, p. 309-328.

VILLWOCK, JA., TOMAZELLI, LJ., LOSS, EL., DEHNHARDT, EA., HORN FILHO, NO., BACHI, FA. and DEHNHARDT, FABA., 1989. Summary of the geology of the coastal province of Rio Grande do Sul. Proceedings of the international symposium on utilization of coastal ecosystems planning, pollution and productivity, Rio Grande/FURG, Rio Grande do Sul, vol. 2, p. 471-484.

VUCETICH, MG., VERZI, DH. and HARTENBERGER, JL., 1999. Review and analysis of the radiation of the South
American Hystricognathi (Mammalia, Rodentia). Académie des Sciences, vol. 329, p. 763-769.

WHITE, MJD., 1978. Modes of speciation. W.H.Freeman \& Company, San Francisco. 455p.

WLASIUK, G., GARZA, JC., and LESSA, EP., 2003. Genetic and geographic differentiation in the Rio Negro tuco-tuco (Ctenomys rionegrensis): inferring the roles of migration and drift from multiple genetic markers. Evolution, vol. 57, no. 4, p. 913-926. 
